\title{
A simple case of drowning?
}

\author{
Kushal Naha, ${ }^{1}$ Sowjanya Naha, ${ }^{1}$ G Vivek, ${ }^{2}$ Manjunath Hande ${ }^{1}$
}

1 Department of Medicine, Kasturba Medical College, Manipal University, Manipal, Karnataka, India ${ }^{2}$ Department of Cardiology, Kasturba Medical College, Manipal University, Manipal, Karnataka, India

\section{Correspondence to} Dr G Vivek,

vivekgraman@gmail.com
To cite: Naha K, Naha $\mathrm{S}$, Vivek $\mathrm{G}$, et al. BMJ Case Rep Published online: [please include Day Month Year] doi:10.1136/bcr-2013201591

\section{DESCRIPTION}

A 55-year-old previously healthy Asian Indian man was brought to our hospital with alleged near drowning. He had been found prone in a shallow pool of water in the grounds near his home by his neighbours. The actual circumstances of the event had not been witnessed. At presentation, he was deeply comatose with a Glasgow Coma Scale of 3/ 15 . He was haemodynamically stable, but hypoxic (arterial oxygen saturation: 65\% on room air) and gasping. Systemic examination revealed bilateral ocular bobbing (video 1). Oculocephalic reflex was absent. The pupils were bilaterally miotic and responded sluggishly to light. Deep tendon reflexes were normal and symmetrical. Plantar response was bilaterally absent. There were no other focal

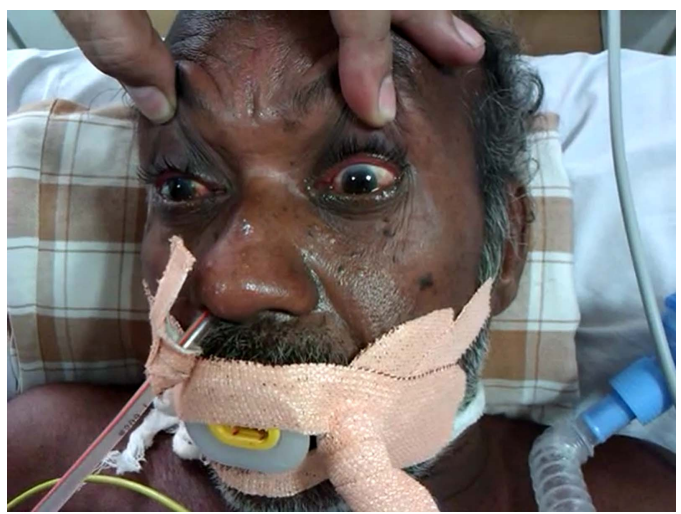

Video 1 Video demonstrates classical ocular bobbing in this patient. Note intermittent conjugate fast downward excursion followed by slow return to primary position after a short tonic delay. neurological signs. Respiratory examination demonstrated bilateral basal crepitations.

The patient was intubated and initiated on mechanical ventilation immediately on admission, in view of suspected aspiration consequent to near drowning.

An emergent cranial CT demonstrated a massive pontine haemorrhage (figure 1, arrows). Retrospectively, it appeared likely that the patient had suffered a stroke, resulting in immediate loss of consciousness and subsequently fallen head first into the pool of water where he was found.

The poor prognosis was explained to his relatives; unfortunately, they were unwilling for further management, and the patient was subsequently discharged against medical advice.

First described by Fisher in 1961, ocular bobbing comprises a distinct group of abnormal involuntary vertical eye movements. ${ }^{1}$ These movements have been subsequently classified on the basis of direction and velocity of the cardinal deviation. The classical form of ocular bobbing, which was observed in this patient, is characterised by intermittent conjugate fast downward excursion followed by a slow return to the primary position after a short tonic delay. ${ }^{2}$ Ocular bobbing is typically associated with pontine lesions including haemorrhage, infarction and tumours, ${ }^{3}$ and usually carries a grim prognosis in such patients, with severe residual deficits in the few patients who do survive. ${ }^{4}$ Other rarer causes include extra-axial posterior fossa masses, diffuse encephalitides and toxic and metabolic encephalopathies. ${ }^{2}$ The pathogenetic mechanisms by which this phenomenon occurs, and the exact neural pathways affected remain unclear. Unfortunately, rapid advances in the field

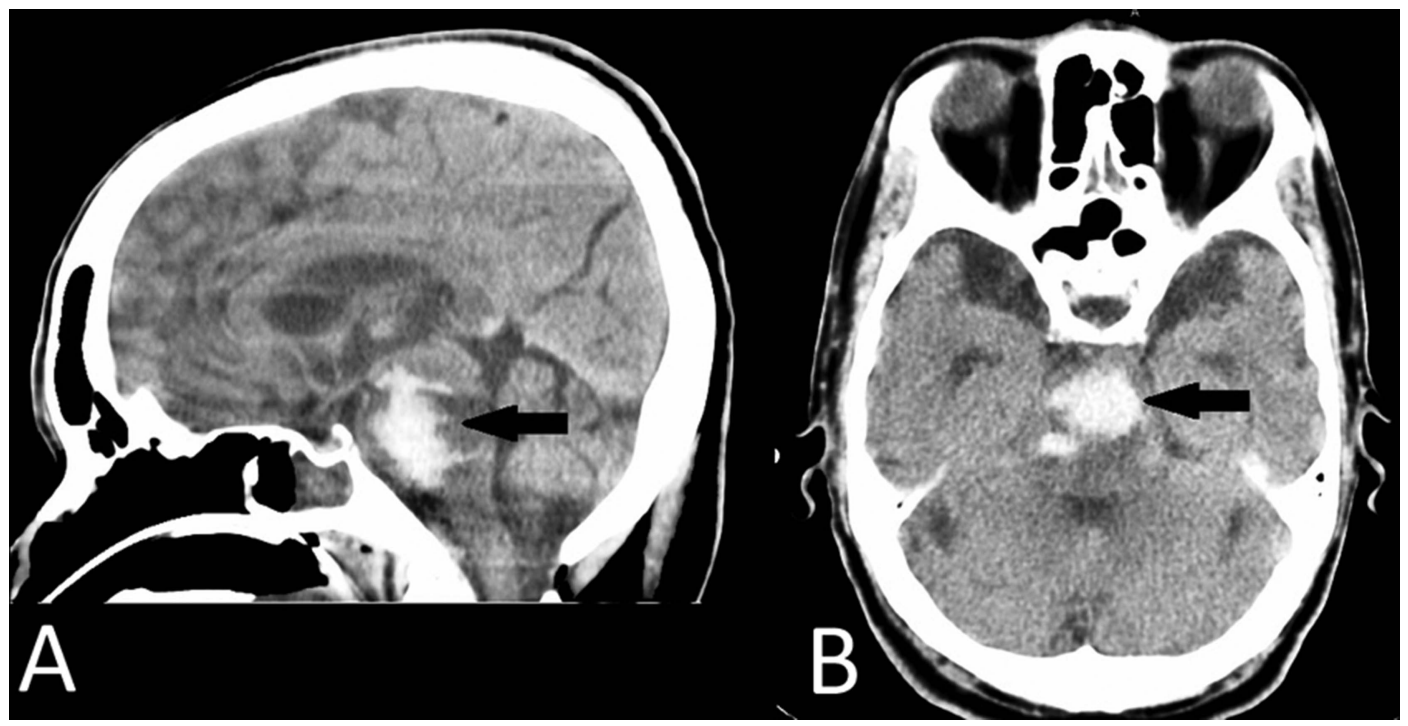

Figure 1 CT of brain showing massive pontine haemorrhage (arrows, A: sagittal section; B: axial section). 
of cerebral imaging have inadvertently led to a reduced need for such clinical signs and resulted in lowered awareness among the medical fraternity.

The presence of the pathognomic and unmistakable neurological sign of ocular bobbing in this instance allowed for the diagnosis of stroke as the true cause for coma, as opposed to simple drowning. In turn, prognostication of this patient's condition was also made possible. Ocular signs such as these are often overlooked or unrecognised in today's era but can provide valuable clues, especially in comatose patients.

\section{Learning points}

- Ocular bobbing is an abnormal involuntary vertical movement of the eyes.

- Ocular bobbing is pathognomic for pontine lesions including haemorrhage, infarction and tumours.

- The presence of ocular bobbing in such patients carries a grim prognosis.
Contributors $\mathrm{KN}, \mathrm{SN}, \mathrm{GV}$ and $\mathrm{MH}$ were involved in the concept, design, definition of intellectual content and literature search. KN, SN, GV were in addition involved in the preparation, editing and review of the manuscript. SN and $\mathrm{MH}$ were involved in clinical care of the patient.

Competing interests None.

Patient consent Obtained.

Provenance and peer review Not commissioned; externally peer reviewed.

\section{REFERENCES}

1 Susac JO, Hoyt WF, Daroff RB, et al. Clinical spectrum of ocular bobbing. J Neurol Neurosurg Psychiatry 1970:33:771-5.

2 Mehler MF. The clinical spectrum of ocular bobbing and ocular dipping. J Neurol Neurosurg Psychiatry 1988;51:725-7.

3 Herishanu YO, Abarbanel JM, Frisher $\mathrm{S}$, et al. Spontaneous vertical eye movements associated with pontine lesions. Isr J Med Sci 1991;27:320-4.

4 Tijssen CC, Ter Bruggen JP. Locked-in syndrome associated with ocular bobbing. Acta Neurol Scand 1986:73:444-6.

Copyright 2013 BMJ Publishing Group. All rights reserved. For permission to reuse any of this content visit http://group.bmj.com/group/rights-licensing/permissions.

BMJ Case Report Fellows may re-use this article for personal use and teaching without any further permission.

Become a Fellow of BMJ Case Reports today and you can:

- Submit as many cases as you like

- Enjoy fast sympathetic peer review and rapid publication of accepted articles

- Access all the published articles

- Re-use any of the published material for personal use and teaching without further permission

For information on Institutional Fellowships contact consortiasales@bmjgroup.com

Visit casereports.bmj.com for more articles like this and to become a Fellow 